\title{
MANAJEMEN RESIKO KEAMANAN E-COMMERCE
}

\author{
Yudi Herdiana,ST,.,M.T \\ Dosen Prodi Teknik Informatika \\ Fakultas Teknologi Informasi, Universitas Bale Bandung (UNIBBA) \\ E-mail: ydherdn@gmail.com
}

\begin{abstract}
Abstrak : Selama dekade terakhir, e-commerce menciptakan peluang baru yang menarik untuk bisnis tetapi juga membawa kerentanan aplikasi web baru dan risiko keamanan transaksi. Manajemen resiko keamanan e-commerce di implementasikan dengan tujuan untuk menyelidiki hubungan antara perasaan konsumen, keamanan toko dan niat pembelian mereka dari toko. Hal ini perlu diketahui dengan mengevaluasi bagaimana persepsi variasi keamanan di antara situs web tanpa kehadiran sosial di satu sisi dan dengan kehadiran sosial di sisi yang lain. Penelitian dilakukan dengan mengevaluasi bagaimana kehadiran sosial dapat mengurangi resiko keamanan yang dirasakan oleh konsumen. Metode penelitian termasuk skenario yang diberikan untuk masing-masing peserta dan mengharuskan untuk melalui pembelian belanja di situs web yang diberikan. Kemudian peserta diberi survei di mana peserta akan mengevaluasi persepsi mereka tentang pengalaman belanja terkait keamanan, kehadiran sosial, dan niat untuk membeli. Penelitian sebelumnya sudah ada penelitian yang dilakukan tentang persepsi keamanan, tetapi tidak satu pun dari studi ini melihat bagaimana jenis toko, berdampak pada persepsi keamanan dan bagaimana kehadiran sosial dapat mengurangi persepsi negatif. Kesimpulan dari penelitian ini bahwa persepsi resiko keamanan dan niat untuk melakukan pembelian berbanding terbalik, itu adalah bahwa semakin besar resikonya, Orang merasa, semakin kecil kemungkinan mereka akan memiliki niat untuk melakukan pembelian. Penelitian ini juga menemukan bahwa jenis toko tidak mempengaruhi persepsi keamanan atau niat untuk melakukan pembelian. Keberadaan sosial juga tidak ditemukan untuk mempengaruhi persepsi keamanan atau niat untuk melakukan pembelian. Pengalaman berbelanja online ditemukan untuk mempengaruhi persepsi resiko.
\end{abstract}

Kata Kunci : resiko keamanan, e-commerce, keberadaan sosial

\section{Pendahuluan}

E-commerce adalah membeli dan menjual barang dan jasa melalui Internet. E-niaga adalah bagian dari e-bisnis sebagaimana ditentukan dalam. E-bisnis adalah struktur yang mencakup tidak hanya transaksi yang berpusat pada pembelian dan penjualan barang dan jasa untuk menghasilkan pendapatan, tetapi juga transaksi-transaksi yang mendukung penghasilan pendapatan. Manajemen risiko teknologi informasi (TI) dapat dianggap sebagai komponen dari sistem manajemen risiko perusahaan yang lebih luas. Di masa lalu, pelanggaran keamanan terjadi di tingkat jaringan sistem informasi organisasi. Internet telah merevolusi banyak segi kehidupan di seluruh dunia. Satu Aspek kehidupan sehari-hari yang telah berubah adalah cara konsumen membeli dan menerima barang. Ini disebut sebagai perdagangan elektronik, proses pembelian, menjual, atau bertukar produk, layanan, atau informasi melalui komputer (Turban, 2012). Banyak bisnis telah beradaptasi dengan model baru ini, menambahkan situs web online atau membuat perusahaan yang benar-benar baru ditemukan online. Bahkan saat ini internet masih 
didominasi oleh yang terbesar pengecer, bahkan dengan perusahaan baru membanjiri internet (Kolesar dan Wayne, 2000). Saat ini, ada dua jenis utama situs web yang menjual barang. Itu pertama adalah situs web klik. Ini adalah situs web yang aslinya hanya sebagai pengecer fisik yang berlokasi di tempat seperti mal. Sekarang perusahaan ini masih bias ditemukan di toko fisik tetapi juga di internet. Banyak perusahaan disesuaikan dengan model bisnis ini untuk menciptakan dua aliran pendapatan. Itu keseimbangan dari kedua bentuk penjualan ini bisa sulit untuk dikelola. Beberapa perusahaan memilih untuk mengintegrasikan dua dunia sementara yang lain memiliki dua yang berbeda sistem untuk setiap aliran pendapatan (Turban, 2012). Perusahaan harus membuat yakin bahwa penciptaan depan toko online tidak berakhir dengan bersaing bagian depan toko fisik mereka dan harus memastikan bahwa mereka sesuai satu sama lain. Beberapa contohnya adalah Walmart atau Nordstrom. Yang lain jenis situs web untuk konsumen biasa disebut sebagai situs web murni.

Ini adalah situs web yang dibuat terutama untuk internet. Tidak ada toko fisik, hanya sebuah situs web. Organisasi-organisasi ini umumnya memiliki lebih sedikit biaya overhead karena jauh lebih murah untuk memiliki depan toko virtual kemudian a lokasi fisik. Mereka hanya dapat memiliki satu gudang yang dapat dikirimkan langsung ke pelanggan, bukan ke toko terlebih dahulu (Turban, 2012). Ada banyak bentuk resiko yang dapat muncul ketika a konsumen melakukan pembelian online, termasuk resiko keamanan, resiko keuangan, dan resiko menghabiskan terlalu banyak waktu. (Flanagin et al., 2014). Persepsi tentang resiko adalah bagian dari gagasan kepercayaan yang lebih besar. Kepercayaan didapatkan berbeda secara online berbelanja daripada berbelanja di toko (Hernandez dan Santos, 2010). Sebuah Resiko penting yang perlu diperiksa adalah resiko keamanan. Resiko keamanan menjadi perhatian bagi konsumen tetapi kekhawatiran ini dapat bervariasi menurut jenis situs web. Jenis-jenis toko berbeda dan orang-orang memiliki perbedaan peluang untuk berinteraksi dengan toko. Ini mungkin berarti pelanggan mungkin memikirkan tingkat keamanan masing-masing toko secara berbeda. Resiko keamanan adalah perhatian nyata untuk pembeli daring dan merupakan sesuatu yang seharusnya menjadi situs web online peduli tentang. Penting untuk melihat apa dampak resiko keamanan dan apa dapat mengurangi resiko sehingga situs web online akan tahu cara membuat yang lebih baik pengalaman berbelanja bagi konsumen. Namun persepsi resiko keamanan untuk situs web mungkin dikurangi dengan pengenalan kehadiran sosial. Sosial Kehadiran adalah sesuatu di situs web yang disertakan untuk memungkinkan konsumen memiliki interaksi pribadi yang nyata dengan penjual di situs web itu. (Zhang et al., 2011). Ini dapat termasuk tetapi tidak terbatas pada obrolan online opsi atau avatar di situs web. Niat untuk membeli adalah sesuatu itu dapat dipengaruhi oleh berbagai faktor, termasuk resiko yang berbeda (Chiu, 2014). Niat untuk membeli pada akhirnya adalah apa yang diinginkan oleh toko online konsumen dan karena itu hubungannya dengan resiko sangat penting.

\section{Tinjauan Pustaka}

Kepercayaan adalah sesuatu yang sangat memengaruhi di mana dan bagaimana orang membeli barang-barang mereka. Secara umum kepercayaan bisa sulit diperoleh di internet karena ada kekurangan jaminan (Kolesar dan Galbraith, 2000). Terlepas dari seberapa sering seseorang menggunakan internet, mereka masih memiliki persepsi keseluruhan yang sama tentang kepercayaan e-commerce (Schmidt et al, 2009). Namun 
kepercayaan memang memiliki peran yang sangat besar dalam e-niaga (Manafi et al, 2011). Pelanggan baru akan menilai situs web dari situs webnya kepercayaan (Almaghrabi et al, 2011). Model pengembangan berbasis untuk kepercayaan adalah cara terbaik untuk menjelaskan aspek kepercayaan dalam hal pembeli hubungan (Hernandez dan Santos, 2010). Perkembangan ini berdasarkan model memiliki tiga sub-kontrak. Mereka berbasis kalkulus, berbasis pengetahuan dan identifikasi. Kepercayaan berbasis kalkulus adalah mengevaluasi kepercayaan berdasarkan menghitung biaya versus manfaat.

Kepercayaan berbasis pengetahuan adalah kepercayaan yang dibangun setelah banyak interaksi antara pengguna dan situs web. Identifikasi-kepercayaan berdasarkan adalah kepercayaan pada pihak lain karena yang tahu apa yang lain ingin pesta dan siapa mereka. Kepercayaan bisa sulit dicapai perdagangan elektronik, karena kepercayaan digunakan untuk dibangun di atas interaksi pribadi dan pertemuan tatap muka. Aplikasi kepercayaan ini juga dapat diperluas ke belanja daring seluler. Kepercayaan positif terhadap belanja online seluler Pengalaman akan mengarah pada penurunan resiko pembelian online yang dirasakan (Shuiging et al., 2015).

\subsection{Resiko penggunaan $E$-commerce}

Resiko penggunaan e-commerce adalah bagian dari ide yang lebih luas dari kepercayaan konsumen. E-niaga kepuasan e konsumen dipengaruhi oleh resiko dan status emosional, yang kemudian pada gilirannya menciptakan loyalitas ke situs web tertentu (Ltifi dan Gharbi, 2012). Resiko memiliki dua level berbeda yang bekerja bersama. Salah satu aspek resiko adalah ukuran masalah yang bisa dibuat dan lalu seberapa besar kemungkinannya hal ini masalah akan benar-benar terjadi (Dowling dan Staelin, 1994). Dua ini dimensi yang berbeda bekerja sama untuk menciptakan tingkat tinggi atau rendah resiko yang dirasakan. Penting untuk menyadari bahwa resiko bukanlah satu dimensi dan dinilai berbeda oleh orang. Orang akan menetapkan besaran yang berbeda untuk setiap tingkat resiko dan probabilitas berbeda dari resiko ini. Penelitian telah dilakukan tentang beberapa jenis resiko yang dihadapi konsumen saat melakukan belanja online. Satu resiko yang telah ditemukan sangat yang penting adalah resiko kehilangan waktu. Orang tidak mau menyia-nyiakan mereka waktu untuk mencari sesuatu di situs web. Titik belanja online adalah untuk temukan sesuatu dengan cepat dan mudah. Selain itu, ditemukan bahwa dalam hal ini Kepuasan elektronik, resiko keuangan tidak menjadi perhatian (Kim dan Benbasat, 2010).

Orang umumnya merasa percaya diri dalam integritas perusahaan untuk menyampaikan produk seperti yang mereka katakan, terutama ketika harganya lebih tinggi menandakan kualitas. Tetapi resiko keuangan bervariasi tergantung pada konsumen tingkat kekayaan. Jika konsumen tidak menghargai kerugian moneter kecil kemudian resiko keuangan tidak akan dihitung ke dalam tingkat resiko keseluruhan (Dowling dan Staelin, 1994). Resiko juga dipengaruhi oleh peringkat tentang situs web (Flanagin et al., 2014). Konsumen akan melakukan penelitian mereka untuk melihat skor rata-rata rating ketika mengevaluasi keberesikoan sebuah situs web. Selanjutnya, dalam hal item dibeli, lebih banyak resiko dikaitkan dengan item sensorik (Sinha dan Singh, 2014).

\subsection{Manajemen Resiko E-commerce}


Dalam lingkungan e-commerce, ada banyak jalan bagi konsumen resiko pengalaman. Satu bidang resiko yang menjadi perhatian utama adalah keamanan resiko. Resiko keamanan mengacu pada ancaman pelanggaran keamanan pribadi informasi yang dikirimkan orang secara online. Ketidakpastian merupakan perhatian utama pembeli dan berdampak pada jumlah potensi keuntungan untuk online pengecer (Joonkyum dan Bumsoo, 2014). Telah ditunjukkan bahwa keamanan masalah mengenai informasi pribadi dan keuangan adalah salah satu yang teratas kekhawatiran pengguna internet (Miyazaki dan Fernandez, 2001). Kekhawatiran ini tertinggi ketika populasi suatu negara baru saja mulai memiliki kesempatan e-commerce (Muhannad dan Ahmed, 2014).

Keamanan informasi dapat didefinisikan sebagai "melindungi informasi dan sistem informasi dari akses yang tidak sah, penggunaan, pengungkapan, gangguan, modifikasi, teliti, inspeksi, pencatatan atau penghancuran "(Turban, 2012). Ada persepsi berbeda tentang aspek keamanan berdasarkan pada individu penggunaan internet. Pengguna ringan adalah seseorang yang tidak menggunakan internet lagi dari 15 jam per minggu sementara pengguna berat adalah siapa saja yang menggunakan internet lebih dari 15 jam per minggu. Pengguna ringan lebih baik dengan praktik kata sandi, mungkin karena mereka pada umumnya lebih berhati-hati karena mereka tidak punya sebanyak kesadaran. Pengguna berat pada gilirannya lebih banyak mengetahui tentang resiko kesadaran dan kesadaran phishing dan lebih baik tentang memperbarui antivirus perangkat lunak. (Schmidt et al., 2009). Namun peningkatan penggunaan tidak menurun persepsi keseluruhan resiko keamanan. Agar orang menyelesaikan pembelian online, mereka perlu merasa aman dan merasa resikonya relatif rendah. Sana adalah peraturan yang diterapkan oleh badan yang mengatur tentang keamanan online, dan khususnya keamanan informasi yang diberikan orang terkait dengan e-commerce.

Banyak orang tidak puas dengan undang-undang ini dan berpikir bahwa mereka tidak cukup ketat untuk sepenuhnya melindungi informasi rahasia mereka (Knezevic dan Jakovic and Strugar, 2014). Ide keamanan informasi sangat penting karena pembeli tidak akan ingin melakukan pembelian secara online jika ada adalah ketidakpastian persepsi karena resiko keamanan (Pavlou, 2007).

Namun, mungkin ada satu cara bagi situs web online untuk mengurangi persepsi resiko keamanan dan itu adalah melalui penggunaan alat kehadiran sosial.

\subsection{Kehadiran Sosial}

Perusahaan yang menggunakan e-commerce perlu memiliki alternatif untuk meningkatkan kepercayaan dan kepuasan konsumen dibandingkan dengan toko fisik tradisional, karena tidak ada interaksi tatap muka. Situs web online tidak memungkinkan bagi pelanggan untuk berinteraksi dengan layanan pelanggan nyata perwakilan. Namun, ada cara-cara tertentu bagi perusahaan untuk membuat ulang interaksi fisik ini. Salah satu alternatif ini adalah kehadiran sosial.

Ketika sebuah perusahaan menggunakan saluran audio atau visual real-time untuk komunikasi, kepercayaan antarpribadi akan meningkat (Bente et al., 2008). Ini akan menjadi sesuatu seperti menyediakan avatar atau melakukan obrolan online langsung 
dengan perwakilan layanan pelanggan. Ketika sebuah perusahaan khusus menggunakan avatar, pengguna akan merasa bahwa ada rasa kehadiran sosial yang lebih besar dan niat membeli (Moon et al, 2013). Avatar itu menyediakan waktu nyata percakapan dengan konsumen dan seseorang yang berafiliasi dengan situs web. Itu penggunaan alat komunikasi modern dapat membantu membuat pengalaman pengguna lebih banyak menyenangkan (Al-maghrabi, et al., 2011). Kehadiran sosial terutama dapat memainkan peran penting saat memeriksa suasana hati konsumen. Kehadiran sosial dapat meningkat mood pelanggan yang kemudian akan meningkatkan niat mereka untuk membeli (Zhang et al., 2011). Kehadiran sosial telah terbukti sangat meningkatkan pengalaman belanja online.

\subsection{Keinginan untuk membeli dalam E-commerce}

Dalam hal belanja, niat untuk membeli sangat penting. Perusahaan ada karena orang benar-benar membeli barang dari perusahaan itu.Niat untuk membeli dapat dipengaruhi oleh berbagai hal termasuk kepercayaan, kegunaan, kepuasan, dan resiko (Dash dan Saji, 2007). Kepuasan keseluruhan dan sikap adalah sesuatu yang memengaruhi niat untuk membeli. Ketika sebuah konsumen memiliki pengalaman positif dengan situs web online dan puas, mereka lebih cenderung melakukan pembelian dan kemudian melakukan pembelian berulang juga (Abdul-Muhmin, 2011). Tidak hanya kepuasan yang penting selama pembelian, ini juga penting untuk fase pasca pembelian untuk pembelian berulang niat (Claudia, 2012). Resiko adalah hal lain yang berdampak negatif niat untuk membeli. Namun efeknya dapat bervariasi berdasarkan pada seberapa banyak toko-toko konsumen online. Ketika seorang konsumen adalah pembelanja online berat, resiko akan tidak mempengaruhi niat untuk membeli sama besarnya dengan ketika konsumen adalah cahaya pembelanja online (Chiu, 2014). Kepercayaan telah ditemukan sebagai mitigasi hubungan untuk niat membeli. Ketika seorang konsumen merasa seperti mereka bias percaya situs web, mungkin karena desain visual yang bagus atau sangat informative situs web, mereka lebih cenderung melakukan pembelian.

\section{Kerangka kerja Penelitian}

Penelitian ini ingin mengetahui dengan menguji resiko dan niat keamanan yang dirasakan konsumen online untuk membeli sehubungan dengan berbagai jenis pengalaman belanja. Itu menguji bagaimana persepsi bervariasi dalam hal jenis toko yang konsumen online menggunakan. Penelitian ini menyelidiki apakah konsumen online memiliki perbedaan persepsi resiko untuk bermain murni dan klik dan mortir jenis e-commerce toko, apakah toko online telah memasukkan kehadiran sosial dan apakah ini memengaruhi niat pembelian konsumen. Di bawah ini adalah model yang diusulkan dari jenis dampak toko persepsi keamanan dan akhirnya mempengaruhi niat untuk membeli. Hubungan ini diusulkan untuk dimitigasi oleh penggunaan kehadiran sosial oleh toko online. 


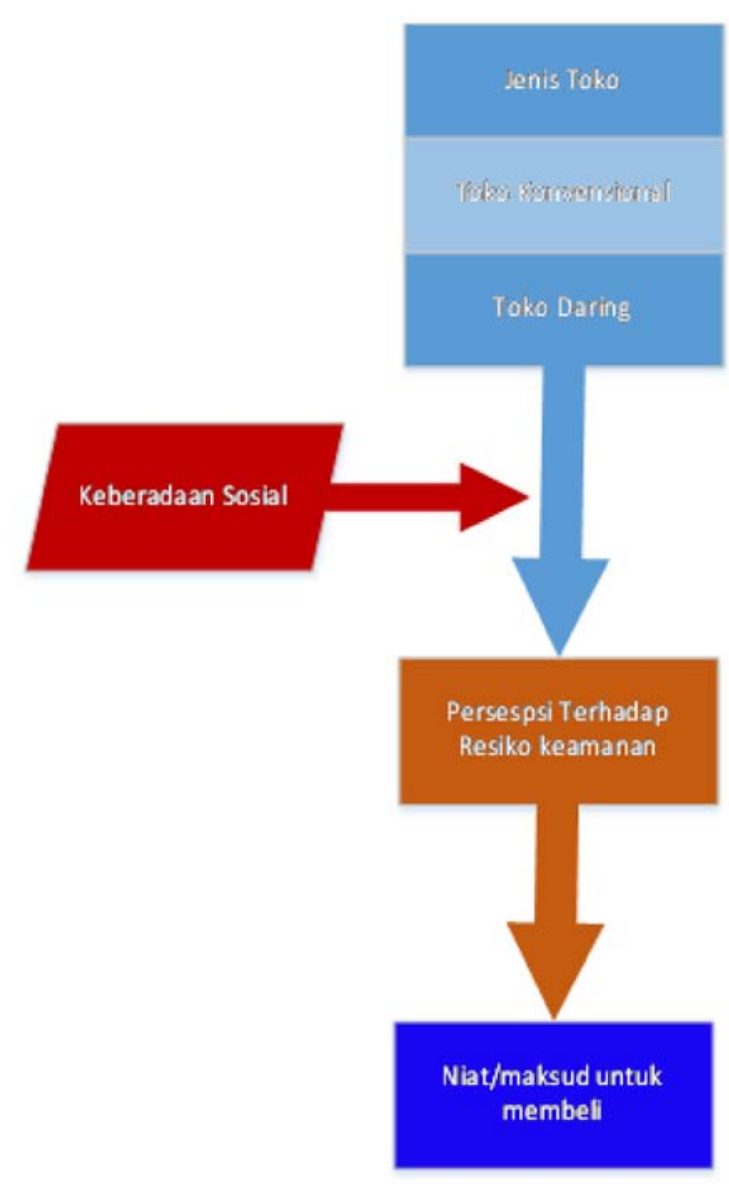

Gambar 1. Model yang digunakan untuk mengetahui bagaimana jenis toko memengaruhi persepsi keamanan dan niat untuk membeli dan bagaimana kehadiran sosial dapat memitigasi hubungan ini.

Untuk menyelidiki persepsi keamanan konsumen online, penelitian ini melihat perbedaan persepsi berdasarkan jenis situs web. Seperti yang telah disebutkan sebelumnya, dua kategori utama situs web orang dapat membeli barang di murni main dan klik dan mortir. Jenis toko diusulkan untuk mempengaruhi persepsi keamanan konsumen. Lebih spesifik, konsumen akan merasakan lebih banyak resiko keamanan saat berbelanja di situs web murni daripada berbelanja di klik dan situs mortir.

Satu variabel moderasi dalam hubungan jenis situs web dan resiko yang dirasakan adalah kehadiran sosial. Kehadiran sosial adalah bagaimana sebuah perusahaan menciptakan suatu interaksi pribadi melalui internet. Penambahan kehadiran social alat diusulkan untuk mengurangi persepsi keamanan. Menambahkan alat yang memungkinkan konsumen untuk memiliki interaksi pribadi dengan toko akan lebih rendah persepsi resiko keamanan.

\section{Hipotesis}

Berikut ini adalah daftar hipotesis yang berasal dari pertanyaan penelitian dan kerangka penelitian. Masing-masing hipotesis ini dibahas secara rinci dengan literatur pendukung. 


\section{H1}

Ada hubungan negatif antara persepsi konsumen tentang a resiko keamanan situs web dan kesediaan mereka untuk membeli produk dari itu situs web. Ketika situs belanja online memiliki resiko yang dirasakan lebih tinggi, konsumen mungkin memiliki niat rendah untuk membeli di situs web itu (Dash dan Saji, 2007). Studi telah menemukan bahwa jika ketidakpastian yang dirasakan tinggi, maka belilah niat terpengaruh secara negatif. Jika konsumen membeli sesuatu dengan keterlibatan pembelian yang relatif tinggi, maka ketidakpastian yang dirasakan terkait resiko lebih tinggi, mengurangi niat pembelian lebih banyak lagi (Pavlou et al., 2007). Resiko adalah masalah penting yang akan dipikirkan konsumen sebelumnya menyelesaikan pembelian mereka, dengan resiko keamanan menjadi salah satu aspek resiko.

Jika ada masalah keamanan, pembeli tidak akan membeli secara online (Pavlou et al., 2007). Meskipun ada manfaat untuk belanja online, ada juga aspek peningkatan resiko, terutama resiko keamanan karena konsumen tidak bias secara pribadi melihat siapa yang mendapatkan informasi mereka dan apa yang sedang dilakukan.

Beberapa toko situs web online datang setelah kehadiran toko fisik depan, jadi konsumen mungkin ke toko di mal dan kemudian dia mengunjungi situs web. Namun, belanja online masih merupakan pengalaman yang berbeda lalu berbelanja di toko. Penelitian menunjukkan bahwa jika suatu perusahaan telah merasakan interaksi pribadi, maka mereka akan memiliki resiko yang dirasakan lebih rendah (Dash dan Saji, 2007). Kepercayaan berkembang dengan sentuhan, tetapi di dunia e-commerce, di sana tidak ada cara bagi perusahaan untuk memberikan sentuhan. Namun, dalam hal a klik dan toko mortir, perusahaan dapat menawarkan "sentuhan" melalui toko fisik (Bente et al., 2008). Persepsi kepercayaan ini harus diperluas ke online mereka situs web karena pelanggan mungkin dapat mengingat interaksi fisik sebelumnya ditemui. Karena ini, klik dan situs mortir mungkin memiliki resiko keamanan yang dirasakan lebih rendah daripada toko bermain murni. Akhirnya, kebanyakan bermain murni situs web tidak memiliki peluang untuk interaksi sosial. Tidak ada kesempatan untuk interaksi tatap muka dan berhubungan dengan perusahaan. Ini mungkin menghasilkan persepsi resiko keamanan yang tinggi.

\section{H2}

Niat pembelian pelanggan akan lebih tinggi dalam klik dan mortir simpan dari situs web murni-putar.

Sikap tentang situs web memiliki pengaruh kuat pada niat pelanggan untuk melakukan pembelian awal dan itu juga mempengaruhi niat untuk mengulang pembelian (AbdulMuhmin, 2011). Menurut sebuah penelitian yang dilakukan di mal virtual, yang merupakan bentuk lain dari belanja internet yang melibatkan dunia virtual, keamanan yang dirasakan mempengaruhi sikap pelanggan dan karena itu mereka niat (Shin dan Shin, 2011). Pelanggan lebih cenderung membuat beli di mal virtual jika mereka merasa ada tingkat keamanan yang tinggi.

Seperti disebutkan, itu adalah hipotesis bahwa keamanan persepsi lebih tinggi untuk klik dan toko mortir, ketika pelanggan memiliki kesempatan untuk melakukan pembelian secara langsung atau online. Persepsi keamanan yang lebih rendah mungkin terkait dengan murni bermain. Telah ditemukan bahwa penggunaan berbagai kegiatan belanja 
bias pengaruh positif seberapa nyaman yang mereka rasakan (Dowling dan Staelin, 1994).

Tidak semua pengalaman belanja dirasakan sama dan orang-orang punya pandangan yang berbeda tentang resiko tergantung di mana mereka melakukan belanja mereka.

\section{H3}

Penambahan alat kehadiran sosial akan mengurangi resiko keamanan di online perbelanjaan. i.e. Ketika ada alat kehadiran sosial di situs web, dianggap resiko keamanan akan menurun. Satu konsep yang mungkin relevan dalam memahami konsumen persepsi resiko yang terkait dengan transaksi e-commerce adalah sosial

kehadiran. Kehadiran sosial membantu menurunkan resiko keamanan konsumen (Pavlou et al., 2007). Kehadiran sosial adalah cara bagi perusahaan untuk memberi pelanggan rasa interaksi pribadi. Perusahaan dengan kehadiran sosial yang tinggi dapat membantu itu perusahaan memberikan interaksi kehidupan nyata dengan pelanggannya. Kehadiran social membantu konsumen merasa seperti informasi yang diungkapkan situs web adalah benar dan representasi akurat dari produk atau layanan. Ini membantu orang lain merasa lebih

aman tentang transaksi mereka. Kehadiran sosial yang dirasakan memiliki dampak langsung tentang bagaimana pelanggan merasakan resiko (Dash dan Saji, 2007). Keberadaan sosial membantu dengan mood pelanggan dan niat membeli (Zhang et al., 2011)

Menambahkan peluang layanan pelanggan online dianggap bermanfaat dan dapat dilakukan umumnya membuat pengalaman belanja online lebih menyenangkan bagi pengguna (Al-maghrabi et al., 2011).

Oleh karena itu, perusahaan e-commerce dapat mengontrol kehadiran dan bantuan social meredakan masalah kurangnya interaksi pribadi di internet. Saya telah menemukan bahwa konsumen akan merasa bahwa perusahaan online memiliki yang lebih tinggi kehadiran sosial jika situs web menawarkan cara bagi pelanggan untuk berkomunikasi langsung dengan perwakilan layanan pelanggan (Bente et al., 2008). Sedangkan ecommerce perusahaan dapat menawarkan sistem pesan instan, cara lain untuk meningkatkan kehadiran sosial adalah melalui penggunaan video atau avatar (Bente et al., 2008) Mereka juga dapat menggunakan berbagai lingkungan online seperti media social halaman dan komunitas virtual (Zhang et al., 2012). Semakin dekat situs web dapat menciptakan kembali interaksi pribadi dan hubungan yang terjalin ketika orang berbicara secara pribadi, semakin tinggi kehadiran sosialnya.

\section{H4}

Ketika orang merasakan kehadiran sosial yang lebih tinggi, mereka akan memiliki pembelian yang lebih tinggi niat. Misalnya, penggunaan alat kehadiran sosial di situs web akan mengarah ke meningkatkan niat untuk melakukan pembelian.

Kehadiran sosial tidak hanya dapat mempengaruhi persepsi resiko keamanan tetapi juga bias juga mempengaruhi niat membeli. Sebagaimana dihipotesiskan sebelumnya, resiko keamanan mungkin memiliki efek terbalik pada niat untuk membeli. Studi ini mengusulkan bahwa menambahkan alat kehadiran sosial tidak akan mengurangi persepsi 
resiko keamanan tetapi juga akan meningkatkan niat untuk membeli. Seperti yang telah disebutkan sebelumnya, menambahkan kehadiran sosial telah ditemukan untuk mengurangi resiko keseluruhan persepsi (Dash dan Saji, 2007). Kehadiran sosial telah ditemukan pengaruh positif kepercayaan dan melalui pengaruh positif kepercayaan, niat untuk membeli telah meningkat (Gefen dan Straub, 2003). Jika perusahaan menginginkan orang merasa lebih nyaman, terutama ketika tidak ada pribadi sebelumnya interaksi, mereka harus melihat untuk menambah garis komunikasi. Perusahaan bias memberikan kesempatan bagi pelanggan untuk merasakan interaksi sosial dengan bantuan kehadiran sosial yang akan meningkatkan niat pelanggan membeli.

\section{Metode Penelitian}

\section{Survei}

Metode penelitian yang digunakan untuk mengumpulkan data untuk penelitian ini adalah survei daftar pertanyaan. Survei digunakan karena ini adalah instrumen yang paling umum digunakan dalam studi tentang belanja online (Dash dan Saji, 2011).

Survei termasuk deskripsi berbagai jenis belanja pengalaman dan pertanyaan tentang tanggapan responden survei tentang pengalaman itu. Ini membuat desain penelitian dari tugas acak menjadi dimanipulasi variabel independen atau kontrol eksperimental. Itu populasi sampel adalah mahasiswa. Kelompok ini dipilih karena peserta sangat mungkin memiliki pengalaman belanja online. Sebagian besar survei tentang belanja online menggunakan peserta yang lebih muda, umumnya kuliah untuk studi mereka (Zhang et al., 2011). Mahasiswa sering berbelanja untuk diri mereka sendiri dan sebagian besar siswa selalu terhubung ke internet. Juga, kuliah siswa akrab dengan konsep kehadiran sosial karena begitu banyak apa yang mereka lakukan online, dan mereka telah mengembangkan cara untuk memutuskan apakah sebuah situs web adalah dapat dipercaya (Zhang et al., 2011). Oleh karena itu, mereka adalah grup yang dapat diterima survei. Kelompok ini terdiri dari campuran wanita dan pria. Dapat dikatakan dengan keyakinan bahwa setiap orang dalam kelompok ini memiliki pengalaman minimal dengan belanja online, terbukti dengan jawaban survei. Karena ini adalah proyek penelitian sarjana, kenyamanan sampel daripada sampel acak dipilih. Murid dengan berbeda nilai diminta untuk berpartisipasi di awal kedua bagian bawah dan atas kelas tingkat yang disetujui oleh profesor mereka. Sebagian besar dari survei ini adalah selesai selama waktu kelas. Survei juga selesai pada akhir berbagai pertemuan kelompok mahasiswa, termasuk perkumpulan mahasiswa. Ada juga insentif untuk menyelesaikan survei.

Penelitian ini melibatkan 200 mahasiswa di lembaga peneliti, mulai dari usia 18 hingga 23 dan nilai baru untuk senior tahun kelima. Itu tingkat respons adalah $90 \%$, karena sebagian besar survei dilakukan di kelas dan di sana adalah insentif untuk menyelesaikan survei.

\section{Instrumen}

Alat penelitian adalah kuesioner terstruktur, dengan pertanyaan yang dating dari berbagai survei yang telah dilakukan tentang belanja online pengalaman. Semua item pengukuran diadaptasi dari penelitian lain.Instrumen survei diperiksa oleh seorang ahli di lapangan, dan selanjutnya diujicobakan pada mahasiswa untuk memastikan survey tersebut bisa dimengerti. 
Peneliti mengembangkan empat skenario belanja online yang berbeda. Setiap peserta membaca salah satu skenario dan kemudian diberikan a kuesioner tentang pengalaman belanja yang dijelaskan. Skenario itu masing-masing empat halaman panjang dan termasuk baik teks dan gambar screen shot dari a situs web yang digambarkan sebagai orang yang menjual perangkat elektronik. Survei instrumen termasuk skenario yang mewakili situs web bermain murni, a situs web bermain murni dengan kehadiran sosial, situs web klik dan mortir, atau klik dan situs mortir dengan kehadiran sosial. Skenarionya sama kecuali sedikit variasi yang menggambarkan jenis situs web. Barang elektronik sesuatu yang dibeli semua orang tanpa memandang jenis kelamin. Sangat mudah ditemukan variasi untuk elektronik yang akan dibeli. Skenario pertama memiliki pengguna berbelanja di toko yang hanya memiliki situs web online dan tidak memiliki pelanggan

pribadi layanan portal online. Skenario kedua menggambarkan situs web untuk toko itu juga memiliki lokasi fisik. Situs web ini tidak memiliki cara untuk pelanggan untuk berinteraksi dengan perwakilan. Skenario ketiga memiliki fitur yang murni mainkan situs web yang memiliki kehadiran sosial, yang merupakan cara bagi pelanggan berinteraksi dengan orang-orang di toko. Keempat situasi serupa dengan yang ketiga tetapi situs web digambarkan sebagai tempat yang mencakup layanan pelanggan online garis bantuan.

Kehadiran sosial dalam skenario dirancang sebagai obrolan online sistem. Skenario ini memberikan deskripsi bersama dengan gambar-gambar yang dituliskan pengalaman obrolan online dengan karyawan waktu nyata. Skenario itu memiliki peserta mengajukan berbagai pertanyaan tentang produk yang dibeli karyawan yang menjawab semua pertanyaan secara detail.

Skenario berjalan peserta melalui online lengkap transaksi. Untuk setiap deskripsi situs web, peserta diberitahu bahwa mereka membeli komputer khusus yang sama di situs web elektronik. Mereka diberitahu bahwa mereka menyelesaikan pembelian sampai ke pembayaran dituntut. Skenario ini akan secara acak ditetapkan untuk setiap subjek, baik situs web dengan kehadiran sosial atau tanpa. Subjek tidak sadar apa situasi lain dan akan dituntun untuk percaya bahwa setiap orang diberikan situasi yang sama.

Setelah peserta membaca skenario, mereka diminta untuk mengisi survei yang menyertakan pertanyaan tentang resiko keamanan, informasi keamanan, kehadiran sosial, niat untuk membeli dan kepercayaan. Karena tidak mungkin bahwa semua pelanggan akan benar-benar membeli jenis barang dari satu dari toko-toko yang dijelaskan, pertanyaan-pertanyaan hanya dapat memeriksa apakah pelanggan akan bersedia melakukan pembelian. Survei kemudian berakhir dengan demografi pertanyaan. Semua pertanyaan dalam kuesioner sama.

Sebagai kesimpulan, masing-masing peserta diberi deskripsi skenario singkat.

Kemudian peserta diminta pertanyaan yang sama tentang mereka pandangan tentang pengalaman belanja dijelaskan. 


\section{Pertanyaan Survei}

Pertanyaan-pertanyaan dikelompokkan bersama dengan konstruk yang sedang diuji untuk mengklarifikasi apa variabel sedang diuji.

\section{Resiko (Risk)}

I. Item Pengukuran

R1 : Saya tidak melihat resiko apa pun dengan membagi informasi pribadi tentang saya transaksi dengan toko online.

R2 : Saya yakin bahwa orang lain tidak dapat mengutak-atik informasi mengenai transaksi saya dengan toko online.

R3 : Saya percaya bahwa teknologi canggih bias tentu memberikan keamanan yang diinginkan untuk saya transaksi dengan toko online.

R4 : Saya rasa uang saya tidak akan dicuri setiap kali saya bertransaksi dengan toko online

\section{Informasi Keamanan (Information Security)}

Item Pengukuran

IS1 : Saya merasa aman dalam memberikan informasi sensitive saat bertransaksi dengan situs web elektronik.

IS2 : Saya akan merasa benar-benar aman memberikan informasi tentang diri saya ke situs web elektronik.

IS3 : Saya akan merasa aman mengirim sensitive informasi ke situs web elektronik.

IS4 : Masalah keamanan informasi sensitif adalah kendala utama untuk pembelian online saya dari situs web elektronik.

IS5 : Secara keseluruhan, situs web yang menjual barang elektronik adalah a tempat yang aman untuk mengirim informasi sensitive

\section{Kehadiran Sosial (Social Presence) \\ Item Pengukuran}

SP1 : Ada rasa kontak manusia di dalam situs web yang saya kunjungi

SP2 : Ada rasa ke-personalan di dalam situs web yang saya kunjungi.

SP3 : Ada rasa kehangatan manusia di dalam situs web yang saya kunjungi.

SP4 : Ada rasa kepekaan manusia di dalam situs web yang saya kunjungi.

SP5 : Selalu ada kemungkinan social jaringan melalui interaksi dengan toko online.

SP6 : Ada rasa ramah saat saya berinteraksi dengan toko online.

SP7 : Ada perasaan memiliki ketika saya berinteraksi melalui toko online.

\section{Niat / maksud untuk membeli (Intention to Purchase)}

\section{Item Pengukuran}

I1 : Saya kemungkinan akan membeli produk situs ini

I2 : Saya akan merekomendasikan situs ini kepada saya teman-teman.

I3 : Saya akan membeli lagi dari situs ini jika saya membutuhkan produk yang akan saya beli 


\section{Kepercayaan (Trust) \\ Item Pengukuran}

T1 : Perasaan keseluruhan dari situs web ini adalah dapat dipercaya.

T2 : Saya mempercayai situs belanja online ini karena mereka menyimpan kepentingan terbaik saya dalam pikiran.

T3 Situs belanja online ini adalah salah satu yang terus janji dan komitmen.

T4 : Saya tidak berpikir bahwa hal-hal bisa jadi salah transaksi saya melalui toko online saya.

T5 : Saya yakin bahwa transaksi saya selesai dengan toko daring dan saya akan selalu transparan

Survei ditutup dengan bagian yang menanyakan tentang demografi peserta. Usia dan jenis kelamin dimasukkan dalam survei ini seperti kebanyakan survei penelitian penelitian lainnya. Area berikutnya bertanya tentang internet pemakaian. Karena survei ini adalah tentang belanja online, penting untuk bertanya berapa lama peserta telah menggunakan internet, seberapa sering mereka menggunakan internet internet dan mengapa mereka menggunakan internet. Pertanyaan demografis terakhir spesifik untuk pengalaman belanja online dan uang yang dihabiskan secara online. Ini penting untuk memeriksa pengalaman para peserta dengan belanja online sebagai ini dapat mempengaruhi persepsi mereka tentang situasi belanja online.

Skala yang digunakan untuk pertanyaan survei adalah skala 5 likert yang merupakan skala yang sangat umum untuk digunakan dan skala yang digunakan untuk pertanyaan semula. Kelima pilihan itu sangat tidak setuju, tidak setuju, tidak setuju atau tidak setuju, setuju, dan sangat setuju, dengan 1 sangat tidak setuju dan 5 sangat setuju.

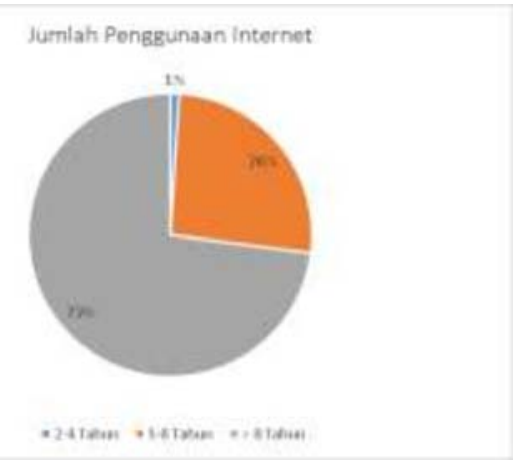

Bagan 1. Perbandingan jumlah tahun yang digunakan peserta Internet.

\section{Analisis Data}

\section{Analisis Deskripsi}

Para peserta diminta untuk menjawab berbagai pertanyaan data demografi. Pertanyaanpertanyaan ini digunakan untuk analisis inferensial dan sebagai kontrol yang mungkin variabel. $13 \%$ dari peserta adalah 18 tahun, 15\% dari peserta $19,16 \%$ dari peserta adalah $20,29 \%$ dari peserta adalah 21 dan 26\% sisanya berusia 22 atau 23 tahun. Dalam hal gender, $41 \%$ dari peserta adalah perempuan dan $59 \%$ adalah laki-laki. 
145 peserta telah menggunakan internet selama lebih dari 8 tahun. $0,5 \%$ dari peserta menggunakan internet kurang dari sekali seminggu, 67,7\% dari penggunaan peserta internet lebih dari 12 kali seminggu, 5\% menggunakan internet dua sampai lima kali lipat minggu, dan $25 \%$ menggunakan internet enam hingga dua belas kali seminggu. Sebagian besar dari peserta dapat diklasifikasikan sebagai pengguna internet berat, menggunakan internet lebih dari sekali sehari. 69\% peserta menggunakan internet untuk berbelanja, sekolah, hiburan, media sosial, dan alasan pribadi Dalam hal belanja online, mayoritas peserta telah belanja online selama dua hingga empat tahun, dengan jumlah rata-rata tahunan pembelian menjadi satu hingga delapan produk. $0,5 \%$ dari peserta membuat nol

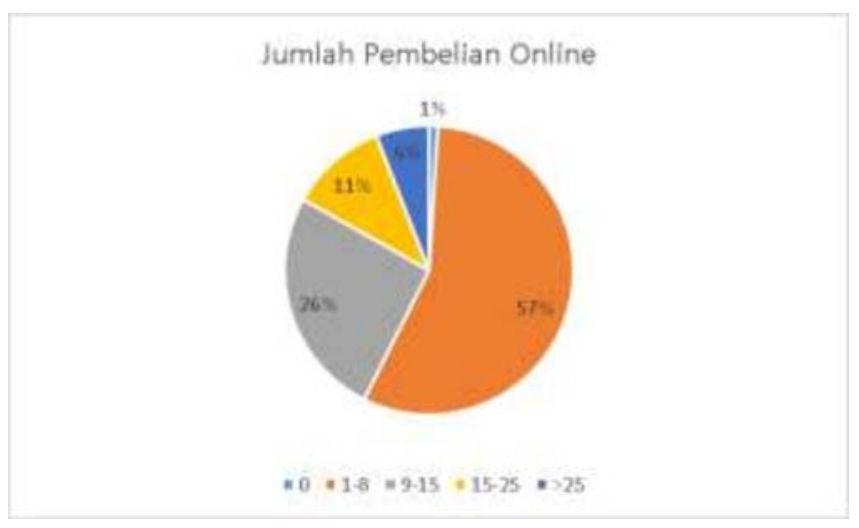

Bagan 2. Perbandingan jumlah peserta pembelian online tahunan

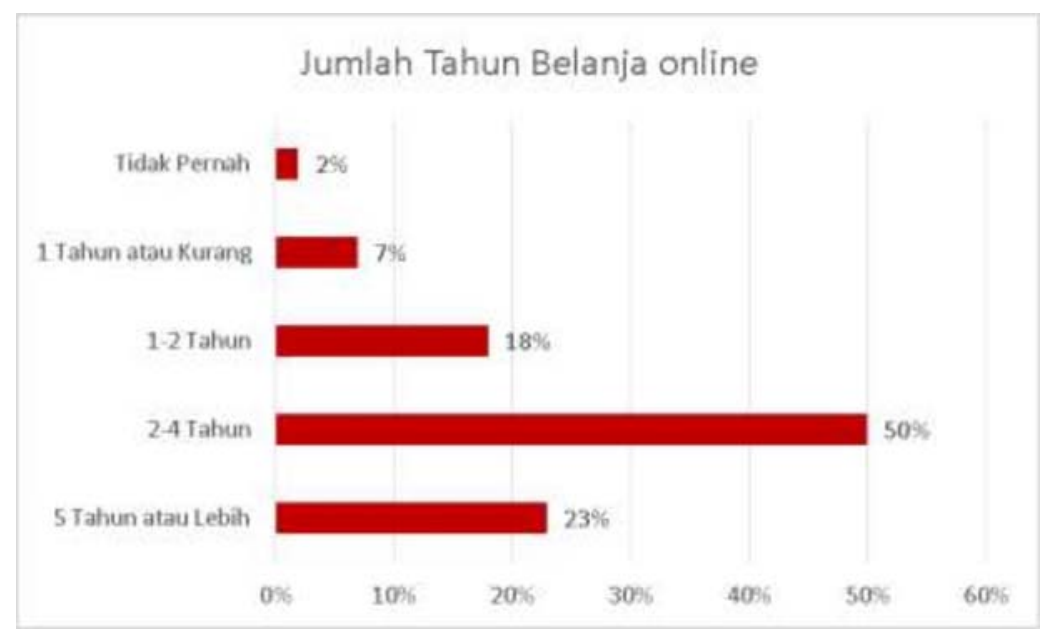

Bagan 3. Perbandingan jumlah tahun peserta telah berbelanja on line.

Pembelian per tahun, 57\% dari peserta membuat satu hingga delapan pembelian online per tahun, 25\% peserta membuat 9 hingga 15 pembelian per tahun, $11 \%$ dari peserta membuat 15 hingga 25 pembelian online setahun, dan 5\% menghasilkan lebih dari 25 pembelian online setahun.

Faktor lain yang perlu dipertimbangkan tentang peserta adalah pendapatan elastis mereka, atau berapa banyak uang yang mereka keluarkan untuk barang-barang yang bukan 
keharusan. Peserta yang membelanjakan $\mathrm{Rp} 0$ untuk barang-barang yang tidak perlu mewakili 1\%, peserta yang membelanjakan Rp 0- Rp 345.000 mewakili $21 \%$, peserta yang membelanjakan $\mathrm{Rp} 345.000$ - Rp 695.000 mewakili 38\%, peserta yang membelanjakan Rp 695.000 - Rp 1.380 .000 mewakili 24\%, peserta yang membelanjakan Rp 1.380.000 - Rp 3.450.000 mewakili 7,5\%, peserta yang membelanjakan Rp 3.450 .000 - Rp 6.900 .000 mewakili 8\%, dan peserta yang menghabiskan lebih dari Rp 6.900 .000 mewakili $1,3 \%$.

\section{Pemeriksaan Manipulasi}

Untuk membuat asumsi tentang data, penting untuk memastikan bahwa variabel yang diukur valid dan reliabel. Bagian berikut akan menjelaskan berbagai tes yang digunakan untuk mengkonfirmasi validitas data. Satu validasi konstruk penting untuk survei adalah menambahkan kehadiran social Apakah dampak perasaan orang tentang belanja online karena ini adalah salah satu dari variabel moderator utama. Untuk menguji ini, ANOVA dijalankan dengan variabel dependen menjadi perasaan tentang kehadiran sosial, dan faktor tetap apakah situs web memiliki kehadiran sosial atau tidak memiliki social kehadiran. Ketika fitur obrolan online ditambahkan ke deskripsi situs web, itu ditemukan bahwa ada lebih banyak perasaan interaksi manusia dengan nilai dari .000. Signifikansi juga ditemukan antara perasaan ramah dan jenis toko memiliki signifikansi .000. Ini menunjukkan bahwa survei tidak secara akurat menggambarkan outlet kehadiran sosial untuk pembeli online melalui sistem obrolan online.

Normalitas data diuji menggunakan statistik deskriptif dalam SPSS. Set pertama data yang diuji adalah variabel dependen kepercayaan, niat dan keamanan bila dibandingkan dengan jenis toko. Kumpulan data kedua adalah variabel dependen yang sama tetapi kali ini mereka dibandingkan dengan dan tanpa kehadiran sosial. Sementara statistik Kolmogorov-Smirnov terungkap bahwa data mungkin melanggar asumsi normalitas pada .000, ini umum untuk ukuran sampel yang besar (Pallant, 2005). Histogram mengungkapkan hal itu skor terdistribusi secara normal. Plot Q-Q Normal juga diplot dalam garis lurus yang cukup Data juga harus diuji untuk multikolinieritas. Ini akan diuji menggunakan regresi untuk menemukan variance inflation factor (VIF).

Ketika niat untuk pembelian adalah variabel dependen VIF untuk kehadiran sosial adalah 1,001 dan VIF untuk jenis toko juga 1,001. Ambang batas normal untuk VIF di bawah tiga sehingga tidak ditemukan korelasi antara variabel.

Semua pertanyaan yang telah digunakan untuk menilai niat, keamanan dan kepercayaan dianalisis menggunakan analisis reliabilitas. Keandalan dari skala untuk keamanan hanya 0,747 berdasarkan Pearson Correlation. Itu keandalan skala untuk niat hanya tertinggi di 0,910 , artinya bahwa skala ini adalah yang paling dapat diandalkan. Setelah memeriksa keandalan skala untuk semua variabel karena semua menggunakan skala yang sama, itu bias menentukan bahwa skala itu dapat diandalkan untuk sampel ini karena nilai di atas 0,7 pada 0,753 (Pallant, 2005).

Pada akhirnya, penelitian ini menguji niat pembelian online pembeli dan bagaimana niat dapat dipengaruhi. Survei termasuk tiga pertanyaan berbeda menanyakan tentang berbagai bidang niat membeli. Di Untuk mengkonfirmasi bahwa pertanyaan-pertanyaan 
ini valid, uji korelasi adalah dilakukan. Dengan menggunakan uji korelasi bivariat, ditemukan bahwa ketiganya pertanyaan sangat berkorelasi, semua dengan korelasi Pearson lebih dari 0,7.

\section{Analisis Inferensial}

Survei mengumpulkan data tentang peserta dan semua variabel ini diuji untuk memeriksa apakah mereka memiliki dampak pada resiko dan niat untuk membeli. Pertanyaan demografis diminta untuk mengukur populasi secara akurat, dan untuk melihat apakah ada varians dalam variabel demografis untuk salah satu variabel dependen. Analisis data inferensial digunakan untuk lebih lanjut menyelidiki hubungan tambahan di antara variabel, dan apakah hasil penelitian ini dapat diterapkan pada populasi yang lebih besar. Itu demografi yang diuji adalah usia, jenis kelamin, pengalaman dengan internet, dan pengalaman dengan belanja online.

Satu-satunya variabel yang ditemukan memiliki dampak pada resiko dan Oleh karena itu niat untuk membeli adalah pengalaman belanja online peserta. Pengalaman belanja online ditentukan oleh jumlah tahun peserta telah melakukan belanja online. Ketika nomor tahun belanja online adalah faktor tetap dan variabel dependen adalah kepercayaan, analisis ANOVA menemukan bahwa keduanya tidak terkait. Ketika variabel dependen adalah resiko keamanan, ada korelasi antara kapan variabel dependen adalah niat untuk membeli ada juga korelasi. Hubungan ini akan dieksplorasi nanti dalam tulisan ini. Pengalaman juga dibandingkan dengan kedua jenis toko dan kehadiran sosial dalam tes MANOVA. Namun tidak ada yang signifikan ketika melihat dampaknya pada niat dan kepercayaan.

Jenis pengalaman lain dengan belanja online dapat didefinisikan sebagai berapa kali seseorang melakukan belanja online. Saat jumlah online pembelian per tahun adalah faktor tetap, ada korelasi antara a

variabel dependen dari resiko keamanan sebagai analisis ANOVA menghasilkan nilai $\mathrm{p}$ dari 0,006. Namun kepercayaan dan niat tidak dipengaruhi oleh jumlah pembelian peserta telah dilakukan online pada tahun lalu. Tidak ada perbedaan yang signifikan antara persepsi laki-laki peserta dan peserta perempuan. Pengujian ANOVA dijalankan dengan jenis kelamin menjadi faktor. Ketika kepercayaan adalah variabel dependen, pengujian terungkap nilai $\mathrm{p}$ yang tidak signifikan. Ketika resiko keamanan tergantung variabel, analisis ANOVA menghasilkan non-signifikansi untuk semua keamanan pertanyaan. Akhirnya, ketika niat untuk membeli adalah variabel dependen, nilai $\mathrm{p}$ adalah 0,134 , karena itu juga tidak signifikan. Tidak ada perbedaan signifikan dalam persepsi kedua kepercayaan, keamanan dan niat untuk membeli ketika usia adalah faktor tetap di ANOVA analisis. Rentang usia peserta cukup kecil (18-24), yang mungkin telah berkontribusi tidak signifikan. Grade juga diuji untuk melihat apakah ada ada artinya. Ketika kelas adalah faktor tetap, tidak ada signifikansi untuk kedua variabel dependen keamanan dan niat dengan nilai-p masing-masing dari .420 dan .695. Tes lain yang dilakukan adalah ANCOVA dengan usia sebagai faktor tetap dan nilai sebagai co-variate. Dengan niat untuk pembelian, usia masih tidak signifikan dengan nilai 0,787. Dengan keamanan, usia juga masih tidak signifikan dengan nilai 0,191 . 


\section{Pengujian Hipotesis}

Survei mengumpulkan data tentang peserta dan semua variabel ini diuji untuk memeriksa apakah mereka memiliki dampak pada resiko dan niat untuk membeli. Pertanyaan demografis diminta untuk mengukur populasi secara akurat,dan untuk melihat apakah ada varians dalam variabel demografis untuk salah satu variabel dependen. Analisis data inferensial digunakan untuk lebih lanjut menyelidiki hubungan tambahan di antara variabel, dan apakah hasil penelitian ini dapat diterapkan pada populasi yang lebih besar. Itu demografi yang diuji adalah usia, jenis kelamin, pengalaman dengan internet, dan pengalaman dengan belanja online.

Penelitian ini mengusulkan lima hipotesis berbeda. Semua hipotesis ini adalah diuji dan dianalisis di bawah ini berdasarkan data yang dikumpulkan melalui daftar pertanyaan. variabel dependen dari uang seperti analisis ANOVA menghasilkan nilai $\mathrm{p}$ dari 0,006 . Namun kepercayaan dan niat tidak berubah oleh jumlah pembelian peserta telah dilakukan online pada tahun lalu.

Tidak ada perbedaan yang signifikan antara persepsi laki-laki peserta dan peserta perempuan. Pengujian ANOVA dijalankan dengan jenis kelamin menjadi faktor. Sebaliknya adalah variabel dependen, Testing terungkap Nilai $\mathrm{p}$ yang tidak signifikan. Ketika orang berpikiran tergantung variabel, analisis ANOVA menghasilkan nonsignifikansi untuk semua orang pertanyaan. Akhirnya, kompensasi untuk membeli adalah variabel dependen, Nilai $\mathrm{p}$ adalah 0,134 , karena itu juga tidak signifikan.

Tidak ada jumlah signifikan dalam persepsi kedua kepercayaan, strategi untuk meningkatkan harga adalah faktor tetap di ANOVA analisis. Rentang waktu peserta cukup kecil (18-24), yang mungkin tidak berkontribusi tidak signifikan. Grade juga untuk melihat apakah ada ada artinya. Ketika kelas adalah faktor tetap, tidak ada signifikansi untuk variabel kedua dependen dan niat dengan Nilai-p masing-masing dari .420 dan .695. Tes lain yang dilakukan adalah ANCOVA dengan waktu sebagai faktor tetap dan nilai sebagai co-variate. Dengan niat untuk pembelian, harga masih tidak signifikan dengan nilai 0,787 . Dengan keamanan, uang juga masih tidak signifikan dengan nilai 0,191 .

Data survei mengumpulkan tentang pelanggan dan variabel itu Ingat untuk memeriksa apakah mereka memiliki dampak pada resiko dan niat untuk membeli. Pertanyaan demografis untuk pengukuran populasi secara akurat, dan untuk melihat apakah ada variasi dalam variabel demografis untuk salah satu variabel tergantung. Analisis data inferensial untuk lebih lanjut variabel hubungan lain, dan juga hasil penelitian ini dapat diterapkan pada populasi yang lebih besar. Itu demografi yang dimasukkan adalah jenis, jenis kelamin, pengalaman dengan internet, dan pengalaman dengan belanja online.

Penelitian ini mengajukan lima hipotesis yang berbeda. Semua hipotesis ini adalah mengawasi dan menganalisis di bawah ini berdasarkan data yang dikumpulkan melalui daftar pertanyaan.

H3

Niat pembelian pelanggan akan lebih tinggi dalam klik dan mortir simpan dari situs web 
murni-putar. Seperti telah dijelaskan, resiko keamanan memengaruhi pembelian niat. Namun data menunjukkan bahwa persepsi resiko keamanan adalah tidak dipengaruhi oleh jenis toko. Pengujian ANOVA juga diselesaikan untuk pastikan apakah niat untuk membeli juga tidak akan dipengaruhi oleh jenis simpan langsung. Ketika jenis toko adalah faktor tetap dan niat untuk pembelian adalah variabel dependen, nilai $\mathrm{p}$ adalah 0,111 . Ini berarti bahwa hubungan tidak signifikan. Oleh karena itu jenis toko tidak ditemukan untuk mempengaruhi niat pelanggan untuk melakukan pembelian di situs web daring. Hipotesa tiga ditolak

\section{H4}

Penambahan alat kehadiran sosial akan mengurangi resiko keamanan di online perbelanjaan. Ditemukan bahwa menambahkan fitur obrolan online ke situs webmeningkatkan perasaan kontak manusia dalam transaksi melalui ANOVA uji faktor tetap kehadiran sosial dengan signifikansi .000. Secara khusus, sistem obrolan memberikan pengguna nuansa yang lebih pribadi dengan signifikansi nilai 0,014 dan juga rasa keramahan dengan nilai signifikansi .000 . Oleh karena itu, jika situs web peduli dengan kurangnya kontak manusia dalam transaksi belanja online khas, menambahkan fitur obrolan pelanggan dengan perwakilan layanan pelanggan dapat mengurangi masalah itu. Namun menambahkan kehadiran sosial ke toko online melalui fitur obrolan online tidak berdampak pada persepsi keamanan. Hipotesis $\mathrm{H} 4$ menyatakan itu resiko keamanan akan lebih rendah jika ada alat komunikasi di tempat. Kapan menganalisis data dari dampak menambahkan kehadiran sosial ke online pengecer pada persepsi resiko, hipotesis nol diterima dengan $\mathrm{p}$ nilai .559 dan nilai $\mathrm{r} 2$.030, disesuaikan dengan .015 . Tidak ada hubungan antara resiko keamanan dan kehadiran sosial pada belanja online situs web. Karena hipotesis ini empat ditolak.

Hubungan ini juga diuji dengan faktor tetap jenis toko. Saat melakukan MANOVA dengan faktor tetap dari jenis dan penyimpanankehadiran sosial dan persepsi resiko keamanan menjadi tergantung variabel, nilai $p$ adalah 0,096 menyebabkan hipotesis nol diterima. Ini oleh karena itu tidak signifikan apa jenis toko atau apakah toko tersebut memiliki kehadiran sosial dalam hal resiko keamanan yang dirasakan.

\section{H5}

Ketika orang merasakan kehadiran sosial yang lebih tinggi, mereka akan memiliki pembelian yang lebih tinggi niat. Meskipun penambahan alat kehadiran sosial tidak berdampak resiko keamanan, masih diuji untuk melihat apakah ada dampak pada pembelian niat. Tes ANOVA dijalankan dengan kehadiran sosial yang diperbaiki faktor dan niat untuk membeli menjadi variabel dependen. Hasil adalah nilai $\mathrm{p} 0,356$ dan nilai F 0,855 , yang berarti bahwa hubungan itu tidak signifikan. Tidak ada hubungan antara kehadiran sosial dan niat untuk membeli sama seperti tidak ada hubungan antara kehadiran social dan persepsi resiko keamanan. Untuk hipotesis ini, analisis data lain yang dilakukan adalah pengujian MANOVA dengan jenis toko dan aspek kehadiran sosial sebagai faktor tetap dan niat untuk membeli menjadi variabel dependen. Itu dihipotesiskan itu kedua variabel dependen ini pada akhirnya akan mempengaruhi niat untuk dibuat pembelian dari situs web online. Analisis data menghasilkan nilai p .320 menyebabkan hipotesis nol diterima. Data menunjukkan itu niat untuk membeli tidak dipengaruhi oleh kombinasi variable jenis toko dan kehadiran sosial. ANCOVA juga 
dilakukan dengan kehadiran sosial sebagai kovariat dan jenis toko sebagai faktor tetap. Niat untuk membeli adalah tergantung variabel. Itu dihipotesiskan bahwa penggunaan alat kehadiran sosial akan mengubah niat untuk membeli sehingga kehadiran sosial akan menjadi kovariat variabel untuk memisahkan variabel keluar. Sekali lagi, baik tipe toko maupun social Kehadiran ditemukan tidak signifikan dengan nilai $\mathrm{p} 0,325$ dan 0,104 masing-masing.

Berdasarkan hasil analisis data, model yang direvisi diusulkan di angka tiga. Baik jenis toko, penggunaan kehadiran sosial maupun kombinasi keduanya berdampak pada persepsi keamanan oleh pelanggan. Namun, persepsi keamanan sangat penting ketika melihat niat untuk membeli sebagai variabel dependen keamanan. Lebih lanjut analisis faktor-faktor lain yang dapat mempengaruhi keamanan dan untuk itu niat, itu ditemukan bahwa pengalaman memainkan peran dalam niat untuk membeli. Ini telah menyebabkan ke model baru yang memeriksa bagaimana pengalaman terkait dengan resiko keamanan dan niat untuk membeli. Ini diuji menggunakan ANOVA dan ANCOVA.

Sebagai bagian dari informasi demografis umum yang dikumpulkan dari penelitian, peserta survei diminta untuk menggambarkan pengalaman mereka dengan belanja online dalam beberapa tahun mereka belanja online untuk. Dengan variabel dependen keamanan, faktor tetap online pengalaman berbelanja menghasilkan nilai $\mathrm{p}, 16$. Menggunakan Fishers Least Analisis Significant Difference (LSD), menunjukkan bahwa ada kebalikannya hubungan antara peserta yang paling banyak tahun belanja online mengalami dan tidak pernah berbelanja online atau berbelanja online kurang dari satu tahun. Dengan lebih banyak pengalaman belanja online, peserta merasakan tingkat keamanan yang lebih tinggi dari belanja online. Lebih khusus lagi, jika seseorang memiliki lebih dari lima tahun pengalaman online belanja, mereka lebih cenderung merasa nyaman dengan keamanan di situs web. Antara satu (tidak pernah online shop) dan lima (toko selama lima tahun), nilainya adalah 0,012 dan batas bawah dari interval kepercayaan adalah negatif. Antara dua (belanja online kurang dari satu tahun) dan lima (toko online selama lima tahun), nilai $\mathrm{p}$ adalah 0,017 dengan batas bawah interval kepercayaan negatif. 


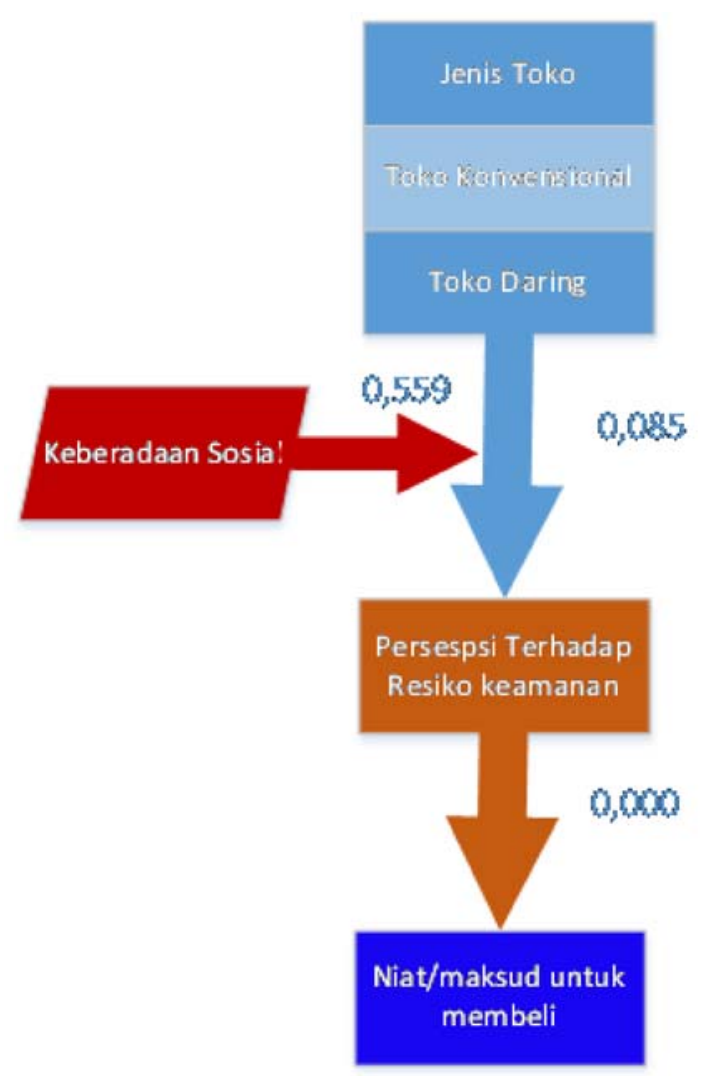

Gambar 2. Model penelitian tentang persepsi konsumen online tentang e-niaga resiko keamanan dan niat konsumen untuk membeli dengan ANOVA nilai signifikansi.

Analisis ANCOVA juga dilengkapi dengan pengalaman belanja online sebagai variabel kovariat dan variabel dependen dari niat untuk membeli dan faktor tetap dari jenis toko. Pengalaman belanja online ditemukan signifikan dengan nilai 0,004. Juga, nilai-p untuk jenis toko menurun, oleh karena itu menjadi lebih signifikan dengan nilai 0,081 .

\section{Diskusi}

Dari analisis data kami, H2, H3, H4, dan H5 tidak didukung, tetapi H1 didukung. Selain itu, model penelitian yang dimodifikasi ini mencakup variabel baru pengalaman belanja online. Meskipun pengalaman belanja online itu awalnya tidak termasuk dalam model penelitian dan hipotesis, itu adalah bagian dari informasi demografis penting yang dikumpulkan dari survei, seperti the variabel kontrol yang mungkin. Variabel pengalaman belanja online ini diuji sebagai kemungkinan mediasi melalui pengujian ANOVA dan ditemukan mempengaruhi persepsi resiko keamanan yang dimiliki peserta yang berbeda, seperti dibahas sebelumnya. Hanya hipotesis pertama yang ditemukan benar, yang menyatakan ituniat untuk membeli di situs web akan terpengaruh secara negatif sebagai persepsi resiko keamanan meningkat. Resiko keamanan masih menjadi perhatian yang valid pembeli online. Ini penting karena ditemukan untuk mempengaruhi apakah pembelian akan benar-benar terjadi. Padahal internet sudah selama bertahun-tahun sekarang, keamanan masih menjadi masalah. Pelanggaran data masih sama seperti biasa dan masih merupakan ancaman yang sah bagi pembeli online. Jika seseorang tidak merasa nyaman dengan keamanan situs web online, mereka tidak akan menyelesaikan pembelian 
mereka dan akan mencari sumber lain untuk membeli apa mereka mungkin mencari. Semakin besar resiko keamanan yang dirasakan, semakin sedikit kemungkinan pembelian akan dilakukan.

Jenis toko tidak memiliki pengaruh terhadap resiko keamanan yang dirasakan, atau niat untuk membeli. Jumlah pengalaman belanja online telah terbukti berdampak pada bagaimana orang melihat pengalaman belanja online mereka dan akhirnya dapat membentuk niat mereka untuk membeli. Hasil penelitian ini menunjukkan bahwa jumlah tahun pengalaman yang dimiliki peserta survei belanja online memengaruhi persepsi resiko keamanan belanja online.

Ini dikonfirmasi oleh penggunaan ANOVA dan ANCOVA pengujian statistik. Variabel ini awalnya ditinggalkan dari hipotesis tetapi merupakan salah satu yang tidak bias dilupakan.

Ketika datang ke belanja online, persepsi dapat dipengaruhi oleh berbagai aspek. Salah satu aspek utamanya adalah pengalaman. Pengalaman dengan internet secara umum dapat mempengaruhi persepsi keamanan. Semakin banyak pengalaman telah dengan internet, semakin sedikit kekhawatiran tentang keamanan informasi akan menjadi (Miyazaki dan Fernandez, 2001). Orang yang memiliki berbagai level pengalaman belanja tampilan online ke berbagai aspek situs web untuk memutuskan apakah mereka ingin melakukan pembelian di situs web tertentu. Khususnya, orang-orang dengan nilai keamanan pengalaman belanja kurang lebih dari mereka yang memiliki tingkat pengalaman normal atau tinggi (Bhatt and Bhatt, 2012).

Salah satu alasan pengalaman itu memiliki pengaruh dalam keamanan Persepsi adalah teori pembentukan sikap, yang menjelaskan hal itu secara langsung pengalaman memperkuat keyakinan tentang suatu hal tertentu. Dalam hal online belanja, hubungan sikap-niat melakukan pembelian ini terkuat dengan pengguna memiliki pengalaman sebelumnya (Crespo et al., 2009).

Berbagai studi telah dilakukan untuk memutuskan berapa banyak pengalaman yang benar-benar terjadi perlu mengatakan bahwa pelanggan memiliki pengalaman dengan belanja online. Memiliki ditemukan bahwa untuk dampak terbesar, pelanggan harus memiliki setidaknya empat tahun pengalaman belanja online (Bertea dan Zait, 2013).

\section{Implikasi Praktis}

Studi ini memberi manajer informasi penting tentang resiko keamanan dalam belanja online. Banyak pengecer sudah mulai menambahkan obrolan online fitur untuk menambahkan cara bagi pelanggan untuk berkomunikasi dengan toko. Menambahkan sebuah sistem obrolan online dapat menciptakan rasa kehadiran sosial untuk situs web. Bisa juga menambah rasa keramahan. Ini dapat membantu reputasi situs web dan toko dan membantu mengambil tempat interaksi fisik yang online pembelanja mungkin ada di toko fisik. Tetapi ini tidak memengaruhi konsumen resiko keamanan yang dirasakan. Karena itu, jika manajer peduli dengan bagaimana pelanggan merasa tentang keamanan situs web e-commerce mereka, menambahkan sebuah sistem obrolan online mungkin bukan solusi untuk masalah ini. Menambahkan sistem obrolan dapat mengubah reputasi 
situs web dan membuat perasaan pembelanja online lebih nyaman tetapi tidak berkorelasi dengan persepsi konsumen resiko keamanan.

\section{Batasan}

Salah satu keterbatasan utama adalah bahwa penelitian ini menggunakan sampel yang nyaman. Kelompok itu sangat selektif dan serupa. Itu bukan sampel acak. Karena penelitian ini berlangsung di kampus perguruan tinggi, itu lebih nyaman gunakan siswa sebagai sampel target. Orang-orang dari kampus yang agak kecil merasa tidak nyaman mengatakan tidak untuk berpartisipasi dalam survei, yang menghasilkan tanggapan tingkat $90 \%$. Dengan tidak melakukan sampel acak, para peserta survei mungkin memiliki sedikit perwakilan untuk populasi pembeli online yang sebenarnya. Juga, dengan tingkat respons yang tinggi, mungkin ada potensi bias sampling.

Untuk penelitian lebih lanjut, kelompok usia yang lebih luas mungkin bermanfaat. Perguruan tinggi siswa tumbuh dengan internet dan karenanya memiliki perbedaan persepsi daripada mereka yang diperkenalkan ke internet di kemudian hari. Studi lain telah menemukan bahwa belanja online lebih disukai di bawah muda usia 30 tahun (Bhatt and Bhatt, 2012). Masalah lainnya adalah cara itu Pengalaman belanja online diciptakan kembali adalah melalui empat halaman deskripsi lengkap dengan foto. Karena bias dengan situs web tertentu, termasuk pengalaman masa lalu dengan situs web atau informasi yang sebelumnya dilihat tentang situs web itu, menggunakan depan toko online yang sebenarnya tidak tampak praktis.

Namun, depan toko bisa dibuat untuk membantu peserta memiliki pengalaman fisik dan langsung dengan situs web. Ini lebih baik waktunya mengkonsumsi harus membuat situs web langsung yang secara akurat meniru yang khas pengalaman belanja online. Jika penelitian melibatkan fisik yang sebenarnya pengalaman, hasil yang berbeda mungkin telah disediakan seperti yang disebutkan sebelumnya oleh membandingkan hasil dengan penelitian lain

\section{Kesimpulan}

Penelitian ini mengusulkan model penelitian untuk persepsi resiko keamanan konsumen belanja online dan bagaimana hal itu berkaitan dengan niat untuk membeli. Itu model mengusulkan bahwa resiko keamanan dipengaruhi oleh jenis toko, baik bermain murni atau klik dan mortir. Penggunaan alat kehadiran sosial diusulkan untuk mengurangi resiko keamanan. Penelitian ini menggunakan data survei untuk mengumpulkan data.

Setelah analisis data selesai, model penelitian dimodifikasi dengan mengajukan pengalaman belanja online adalah penentu utama dalam bagaimana seorang konsumen akan merasakan resiko keamanan dan karena itu akan mempengaruhi niat mereka untuk membeli.Salah satu tujuan dari penelitian ini untuk menyelidiki apakah ada hubungan antara jenis toko online dan persepsi konsumen resiko keamanan. Itu dihipotesiskan bahwa ketika konsumen berbelanja pada murni bermain situs web mereka akan memiliki persepsi resiko keamanan yang lebih tinggi daripada kapan mereka berbelanja di toko klik dan mortir. Ketika sebuah toko memiliki lebih tinggi resiko keamanan yang dirasakan, konsumen cenderung memiliki niat untuk membuat Pembelian. Tujuan lain dari penelitian ini adalah untuk menguji apakah penggunaan kehadiran sosial di situs web 
belanja online memiliki efek mengurangi pada persepsi resiko keamanan dan karena itu memiliki efek positif pada niat untuk melakukan pembelian dari situs web.

Penelitian menggunakan kuesioner survei untuk mengumpulkan data. Survei dikelola di kampus, mengandalkan sampel kenyamanan. Itu tingkat respons adalah $90 \%$. Setelah mengumpulkan hasil dari 200 peserta survei, datanya adalah dianalisis. Data dianalisis melalui ANOVA dan MANOVA dan ANCOVA. Bukan hanya hipotesis yang diuji, tetapi analisis deskriptif dilengkapi dengan analisis inferensial. Ditemukan bahwa jenis toko tidak mempengaruhi persepsi resiko atau niat membeli yang bisa mengarah pada kesuksesan lebih online saja situs belanja, orang-orang seperti Amazon.com atau ebay.com. Kehadiran sosial adalah juga ditemukan tidak berdampak pada persepsi resiko keamanan atau niat untuk membeli.

Pengalaman adalah faktor utama yang ditemukan memengaruhi online kekhawatiran keamanan dan resiko pembeli. Ditemukan bahwa niat untuk membuatnya pembelian belanja online memiliki hubungan langsung dengan resiko keamanan. Jika ada persepsi resiko yang lebih rendah, ada lebih banyak niat untuk membuat membeli. Karena temuan ini, itu bisa berarti belanja online akan menjadi lebih luas diterima di tahun-tahun mendatang. Karena semakin banyak orang beralih ke internet untuk membeli barang yang mungkin mereka butuhkan, akan ada lebih banyak orang pengalaman lebih. Ini harus mengurangi persepsi belanja online resiko keamanan di masa depan.

\section{Daftar Pustaka}

[1] Al-maghrabi, T., Dennis, C., Halliday S.V., BinAli, A. (2011). Determinants of customer continuance intention of online shopping. Journal of Business Science and Applied Management, 6(1), 41-66.

[2] Ba, S., \& Pavlou, P.A. (2002). Evidence of the effect of trust building technology in electronic markets: Price premiums and buyer behavior. MIS Quarterly, 26(3), 24368. http://dx.doi.org/10.2307/4132332.

[3] Bente, G., Ruggenberg, S., Kramer, N.C., \& Eschenburg, F. (2008). Avatarmediated networking: Increasing social presence and interpersonal trust in net-based collaborations. Hum Commun Res, 34(2), 287-318. http://dx.doi.org/10.1111/j.1468-2958.2008.00322.x.

[4] Dash, S., \& Saji, K.B. (2007). The role of consumer self-efficacy and website social presence in customers' adoption of b2c online shopping: An empirical study in the Indian context. Journal of International Consumer Marketing, 20(2), 33-48. http://dx.doi.org/10.1300/j046v20n02_04

[5] Dowling, G.R., \& Staelin, R. (1994). A model of perceived risk and intended risk handling activity. Journal of Consumer Research, 21(1), 119-34. http://dx.doi.org/10.1086/209386.

[6] Hernandez, J. M., \& Santos, C.C. (2010). Development-based trust: Proposing and validating a new trust measurement model for buyer-seller relationships.

[7] Joonkyum, L., \& Bumsoo, K. (2014). Assortment optimization under consumer choice behavior in online retailing.

[8] Kang, Y., Park, J., \& Liu, J. (2012). A study on the online shopper's selfdisclosure. Academy of Marketing Studies Journal, 16(1), 19-38.. 
[9] Kim, D., \& Benbasat, I. (2009). Trust-assuring arguments in B2C ecommerce: Impact of content, source, and price on trust. Journal of Management Information Systems, 26(3), 175-206. http://dx.doi.org/10.2753/mis0742-1222260306.

[10] Knezevic, B., Jakovic, B., \& Strugar, I. (2014). Potentials and problems of internet as a source of purchasing information: Experiences and attitudes of university students in Croatia. Business, Management \& Education, 12(1), 138-58. http://dx.doi.org/10.3846/bme.2014.10

[11] Kolesar, M.B., \& Galbraith, R. W. (2000). A services-marketing perspective on eretailing: Implications for e-retailers and directions for further research.

[12] Ltifi, M., \& Gharbi, J. (2012). E-satisfaction and e-loyalty of consumers shopping online. Journal of Internet Banking and Commerce, 17(1).

[13] Manafi, M., Roozbeh, H., Aghapour, A. H., Salehi, M., Aghaei, M. R., \& Gheshmi, R. (2011). Trust in e-commerce.

[14] Miyazaki, A., \& Fernandez, A. (2001). Consumer perceptions of privacy and security risks for online shopping. J Consum Aff, 35(1), 27-44. http://dx.doi.org/10.1111/j.1745-6606.2001.tb00101.x.

[15] Moon, J. H., Kim, E., Choi, S. M., \& Sung, Y. (2013). Keep the social in social media: The role of social interaction in avatar-based virtual shopping. Journal of Interactive Advertising, 13(1), 14-26. http://dx.doi.org/.10.1080/15252019.2013.768051

[16] Muhannad, K., \& Ahmed, G. (2014). Customer perceptions of e-commerce in the United Arab Emirate. International Journal of Global Business, 7(1), 95-109.

[17] Pavlou, P. A., Liang, H., \& Xue, Y. (2007). Understanding and mitigating uncertainty in online exchange relationships: A principal-agent perspective.

[18] Preibusch, S., Kübler, D., \& Beresford, A. R. (2013). Price versus privacy: an experiment into the competitive advantage of collecting less personal information. Electronic Commerce Research, 13(4), 423-455. http://dx.doi.org/10.1007/s10660013-9130-3

[19] Schmidt, M. B., Chen, J. Q., Phan, D. D., \& Arnett, K. P. (2009). Security perceptions of e-commerce users. Journal of Internet Commerce, 8(1/2), 4457.http://dx.doi.org/10.1080/15332860903341307

[20] Shin, D., \& Shin, Y. (2011). Consumers' trust in virtual mall shopping: the role of social presence and security. Int $\mathrm{J}$ Hum Comput Interact, 27(5),450-75. http://dx.doi.org/10.1080/10447318.2011.552060

[21 Sinha, P., \& Singh, S. (2014). Product characteristics vis-à-vis consumers'risk perception: A conceptual study of online shopping. IUP Journal Of Marketing Management, 13(2), 40-57.

[22] Turban, E. (2012). Electronic commerce. Upper Saddle River, NJ: Prentice Hall.

[23] Yang, S., Chen, Y., \& Wei, J. (2015). Understanding consumers' web-mobile shopping extension behavior: A trust transfer perspective. Journal of Computer Information Systems, 55(2), 78-87. http://dx.doi.org/ 10.1080/08874417.2015.11645759

[24] Zhang, H., Lu, Y., Shi, X., Tang, Z., \& Zhao, Z. (2012). Mood and social presence on consumer purchase behaviour in $\mathrm{C} 2 \mathrm{C}$ E-commerce in Chinese culture. Electronic Markets, 22(3), 143-54. http://dx.doi.org/10.1007/s12525-012-0097-z 